\title{
EFFECT OF DIABETES AND INSULIN ON THE MAXIMUM CA- PACITY OF THE RENAL TUBULES TO REABSORB GLUCOSE ${ }^{1}$
}

\author{
By SAUL J. FARBER, EUGENE Y. BERGER, AND DAVID P. EARLE
}

(From the Department of Medicine, New York University College of Medicine, New York)

(Submitted for publication September 5, 1950; accepted, October 30, 1950)

Glycosuria occurs whenever the amount of glucose filtered by the glomeruli exceeds the reabsorptive capacity of the tubules. The glycosuria of diabetes, therefore, is dependent not only on the degree of hyperglycemia but also on the concurrent glucose reabsorptive capacity.

A number of observers have noted that diabetic patients sometimes may have little or no glycosuria in spite of hyperglycemia $(1,2)$. Mirsky and Nelson (2) have attributed this phenomenon to decreased glomerular filtration rate, especially among elderly patients, or to an increase in the glucose reabsorptive capacity of the tubules.

Glucose reabsorption depends on an active transport system which is undoubtedly enzymatic in na-

1 This work was supported by a grant from the U. S. Public Health Service. ture (3) and, therefore, is limited by a maximum rate, designated $\mathrm{Tm}_{\mathrm{G}}$. This transport system appears to be subject to a variety of functional controls including hormones. Indeed, slight reduction in $\mathrm{Tm}_{\mathrm{G}}$ after the administration of insulin has been observed in the dog (4), while thyroid extract has been noted to increase $\operatorname{Tm}_{G}(5)$.

The present study represents an evaluation in man of the effects of diabetes and of insulin on the maximum ability of the tubules to reabsorb glucose.

\section{SUBJECTS AND METHODS}

Glomerular filtration rate (GFR) and Tma were studied in 12 diabetic patients. Nine non-diabetic subjects served as controls. Pertinent clinical data are summarized in Table I. The duration of diabetes was not known with certainty in each instance, but was mild to moderate

TABLE I

Clinical data

\begin{tabular}{|c|c|c|c|c|c|c|c|c|c|}
\hline Patient & Sex & Age & $\begin{array}{c}\text { Surface } \\
\text { area }\end{array}$ & $\begin{array}{c}\text { Known } \\
\text { duration } \\
\text { diabetes }\end{array}$ & Insulin requirements & $\begin{array}{l}\text { Fasting } \\
\text { plasma } \\
\text { glucose }\end{array}$ & $\begin{array}{l}\text { Blood } \\
\text { pressure }\end{array}$ & Urine & Fundi \\
\hline & & & $(s q . m)$. & (years) & (units per day) & $\underset{\text { per cent })}{(m g m .}$ & $(\mathrm{mm} . \mathrm{Hg})$ & (prolein) & \\
\hline 1 & $\mathbf{M}$ & 49 & 1.62 & 1 & $10 \mathrm{PZI}$ & 120 & $110 / 74$ & 0 & normal \\
\hline 2 & M & 61 & 1.91 & 2 & none & 123 & $112 / 68$ & 0 & normal \\
\hline 3 & $\mathbf{M}$ & 37 & 1.75 & 7 & $35 \mathrm{PZI}$ & 204 & $120 / 90$ & $5 \mathrm{~mm}$. per & normal \\
\hline 4 & $\mathbf{M}$ & 38 & 1.83 & 3 & 40 PZI, 15 Reg. & 287 & $128 / 70$ & 0 & slight sclerosis \\
\hline 5 & $\mathbf{M}$ & 53 & 1.71 & 2 & none* & 368 & $160 / 80$ & 0 & normal \\
\hline 6 & $\mathbf{M}$ & 43 & 1.91 & 23 & 80 Reg. & 455 & $120 / 80$ & 0 & normal \\
\hline 7 & $\mathrm{~F}$ & 45 & 1.70 & 3 & 5 Reg. & 115 & $130 / 80$ & 0 & normal \\
\hline 8 & $\mathrm{~F}$ & 73 & 1.74 & 1 & none & 145 & $160 / 90$ & 0 & sclerosis vessels \\
\hline 9 & $\mathrm{~F}$ & 65 & 1.64 & 9 & $15 \mathrm{PZI}$ & 159 & $140 / 90$ & 0 & sclerosis vessels \\
\hline 10 & $\mathrm{~F}$ & 45 & 1.64 & 7 & $10 \mathrm{PZI}$ & 173 & $145 / 80$ & $1+$ & few patches \\
\hline $\begin{array}{l}11 \\
12\end{array}$ & $\begin{array}{l}\mathrm{F} \\
\mathrm{F}\end{array}$ & $\begin{array}{l}43 \\
40\end{array}$ & $\begin{array}{l}1.62 \\
1.68\end{array}$ & $\begin{array}{r}3 \\
16\end{array}$ & $\begin{array}{l}5 \text { Reg. } \\
45 \text { PZI, } 20 \text { Reg. }\end{array}$ & $\begin{array}{l}200 \\
480\end{array}$ & $\begin{array}{l}120 / 88 \\
120 / 80\end{array}$ & $\begin{array}{l}5 \mathrm{~mm} . \% \\
0\end{array}$ & $\begin{array}{l}\text { slight } \mathrm{A}-\mathrm{V} \text { nicking } \\
\text { normal }\end{array}$ \\
\hline $\begin{array}{l}13 \\
14 \\
15 \\
16 \\
17 \\
18 \\
19 \\
20 \\
21\end{array}$ & $\begin{array}{l}\mathbf{M} \\
\mathbf{M} \\
\mathbf{M} \\
\mathbf{M} \\
\mathbf{M} \\
\mathbf{M} \\
\mathrm{F} \\
\mathrm{F} \\
\mathrm{F}\end{array}$ & $\begin{array}{l}43 \\
27 \\
53 \\
48 \\
23 \\
47 \\
44 \\
28 \\
25\end{array}$ & $\begin{array}{l}1.65 \\
1.87 \\
1.72 \\
1.95 \\
1.66 \\
1.74 \\
1.78 \\
1.52 \\
1.67\end{array}$ & \multicolumn{2}{|c|}{$\begin{array}{l}\text { Non-diabetic } \\
\text { Non-diabetic } \\
\text { Non-diabetic } \\
\text { Non-diabetic } \\
\text { Non-diabetic } \\
\text { Non-diabetic } \\
\text { Non-diabetic } \\
\text { Non-diabetic } \\
\text { Non-diabetic }\end{array}$} & & & \multicolumn{2}{|l|}{$\begin{array}{l}\text { normal } \\
\text { normal } \\
\text { normal } \\
\text { normal } \\
\text { normal } \\
\text { normal } \\
\text { normal } \\
\text { normal } \\
\text { normal }\end{array}$} \\
\hline
\end{tabular}

* Resistant to subcutaneous insulin, treated by diet alone. 
in severity as evidenced by the daily insulin requirements and the fasting plasma glucose levels. None of the diabetic patients had established hypertensive disease. Minimal proteinuria was observed in two patients, while one patient had slight proteinuria and a few patches of exudate in the fundi. Mild to moderate sclerosis of the retinal vessels was observed in four patients.

All experiments were performed in the post-absorptive state. Insulin therapy was witheld for 24 hours prior to a study. In each study $T m_{\text {; }}$ was measured for three or more consecutive periods. In 15 of the 21 studies, inulin clearance was measured for three 15 to 20 minute periods prior to the start of the glucose infusions. Priming doses of 50 per cent glucose in water were given intravenously in amounts calculated to raise the plasma glucose to between 500 and $800 \mathrm{mgm}$. per cent. The plasma glucose level was maintained by a constant intravenous infusion delivered by a calibrated pump. The sustaining infusion for the diabetic patients contained 15 to 25 per cent glucose and was delivered at $3 \mathrm{ml}$. per minute. Twenty minutes were allowed for equilibration between the start of sustaining infusion and the beginning of the ten minute urine collections.

In the insulin experiments, regular Lilly or Squibb preparations were used. Twenty units were given intravenously as a priming dose while 2 units per minute were delivered in the sustaining infusion. Again, 20 minutes were allowed for equilibration before the start of the ten minute collection periods.

Inulin clearance was used as a measure of glomerular filtration rate. The plasma inulin level was maintained between 30 and $40 \mathrm{mgm}$. per cent. All urines were collected through a multi-eyed catheter. The bladder was washed out at the end of each period except when the urine flow exceeded $10 \mathrm{ml}$. per minute. Arterial bloods were obtained at the mid point of each period.

Inulin was determined by the Harrison modification (6) of the Alving, Rubin and Miller method (7). Prior to the inulin measurement, glucose was removed from each $1 \mathrm{ml}$. sample of plasma and diluted urine by exposure for 30 minutes to $6 \mathrm{ml}$. of a 30 per cent yeast suspension. Glucose was determined by a modification (4) of the Folin method. Glycolysis was inhibited by the addition of a small amount of fluoride to each blood sample, which was centrifuged immediately. The plasma was drawn off within 15 minutes of collection.

\section{Plasma Glucose Levels and the Ratios of Glucose Load to $T m_{G}$}

The ranges of arterial plasma glucose levels achieved during the measurement of $\mathrm{Tm}_{\mathrm{G}}$ alone and of $\mathrm{Tm}_{\mathrm{G}}$ during the administration of insulin are recorded in Table II. Generally the plasma glucose level was between $\mathbf{5 0 0}$ and $800 \mathrm{mgm}$. per cent and rarely varied more than 50 mgm. per cent during the measurement of $\mathrm{Tm}_{\mathrm{G}}$ alone. Following the administration of insulin the plasma glucose level with one exception declined in spite of the continued glucose infusion. The fall in plasma glucose during the measurement of $\mathrm{Tm}_{\mathrm{G}}$ while insulin was being
TABLE II

Plasma glucose levels and ratios of glucose load to $T m_{\mathrm{G}}$

All plasma glucose levels done on arterial blood. Initial and final plasma glucose levels are recorded for the three periods that made up each observation, except those marked* which consisted of five periods and those marked $\dagger$ which consisted of four ten minute periods.

\begin{tabular}{|c|c|c|c|c|}
\hline \multirow{2}{*}{ Patient } & \multicolumn{2}{|c|}{ Plasma glucose, $m g m$. per cent } & \multicolumn{2}{|c|}{ Ratio glucose load to $\mathrm{Tm}_{\mathrm{G}}$} \\
\hline & $T \mathrm{~m}_{\mathrm{G}}$ alone & $\operatorname{Tm} \mathrm{m}_{\mathrm{G}}+$ Insulin & Tma alone & Tm $\mathrm{G}+$ Insulin \\
\hline $\begin{array}{r}1 \\
2 \\
3 \\
4 \\
5 \\
6 \\
7 \\
8 \\
9 \\
10 \\
11 \\
12\end{array}$ & $\begin{array}{l}645-735 \\
450-420 \\
554-616 \\
567-606 \\
470-480 \\
690-721 \\
605-640 \\
438-425 \\
624-636^{*} \\
624-654^{*} \\
765-840^{*} \\
885-900\end{array}$ & $\begin{array}{l}703-675 \\
420-402 \\
616-546 \\
548-533 \\
460-440 \\
683-613 \\
640-550 \\
425-348 \\
610-550^{*} \\
666-545^{*} \\
840-780^{*} \\
930-870\end{array}$ & $\begin{array}{l}2.01 \\
1.34 \\
1.54 \\
1.75 \\
1.25 \\
2.12 \\
1.71 \\
1.43 \\
1.77 \\
1.62 \\
2.30 \\
2.55\end{array}$ & $\begin{array}{l}2.48 \\
1.33 \\
1.69 \\
1.93 \\
1.24 \\
1.92 \\
1.91 \\
1.58 \\
1.76 \\
1.65 \\
2.59 \\
2.06\end{array}$ \\
\hline 12 & \multicolumn{2}{|r|}{ Average } & 1.64 & 1.70 \\
\hline $\begin{array}{l}13 \\
14 \\
15 \\
16 \\
17 \\
18 \\
19 \\
20 \\
21\end{array}$ & $\begin{array}{c}910-990 \\
590-600 \\
1022-1035^{*} \\
585-600 \dagger \\
504-500 \\
812-798 \dagger \\
580-630 \\
410-460 \\
660-717\end{array}$ & $\begin{array}{c}-\overline{6} \\
620-510 \\
1404-1368^{*} \\
585-585 \dagger \\
- \\
770-693 \\
- \\
-\end{array}$ & $\begin{array}{l}2.56 \\
2.52 \\
3.44 \\
1.77 \\
1.78 \\
2.98 \\
1.72 \\
1.44 \\
2.34\end{array}$ & $\begin{array}{l}- \\
2.15 \\
4.38 \\
2.02 \\
- \\
2.68 \\
-\end{array}$ \\
\hline 21 & \multicolumn{2}{|r|}{ Average } & 2.28 & \\
\hline
\end{tabular}

administered averaged $57 \mathrm{mgm}$. per cent with a range of 0 to $121 \mathrm{mgm}$. per cent. A glucose load to $\mathrm{Tm}_{\mathrm{G}}$ ratio of 1.5 or higher is generally accepted (4) as being adequate to completely saturate the normal tubular reabsorptive capacity for glucose. Ratios exceeding this value were achieved in all but two of the diabetic patients and in all but one of the non-diabetic subjects. The lowest ratio of 1.25 occurred in a patient with an unusually high $\mathrm{Tm}_{\mathrm{G}}$. Any error introduced by a too low load of glucose would result in a falsely low $\mathrm{Tm}_{\mathrm{G}}$. Because of the reduction in $\mathrm{Tm}_{\mathbf{G}}$ resulting from insulin administration, the glucose load to $\mathrm{Tm}_{\mathrm{G}}$ ratio was maintained after insulin, even though the load decreased because of the falling plasma glucose level.

\section{RESULTS}

The values for glomerular filtration rate (GFR), $T \mathrm{~m}_{\mathrm{G}}$ and the ratio of GFR to $T \mathrm{~m}_{\mathrm{G}}$ observed in 12 diabetic and in nine normal subjects are recorded in Table III along with normal values established by Smith (8). GFR and $\mathrm{Tm}_{\mathrm{q}}$ values are corrected to a surface area of $1.73 \mathrm{sq} . \mathrm{m}$.

The group of normal subjects is not large, but their filtration rates and $\mathrm{Tm}_{\mathbb{G}} \mathrm{S}$ are in the normal 
range established by Smith and his associates (8), with the exception of one $\mathrm{Tm}_{\mathrm{G}}$ (patient 20, Table III) which exceeded the mean normal plus 2 standard deviations $(375+2 \times 79.7=543 \mathrm{mgm}$. per minute for males, $303+2 \times 55.3=414 \mathrm{mgm}$. per minute for females).

The diabetic group is also small and, although the mean $\mathrm{Tm}_{\mathrm{G}}$ for both males and females are greater than the corresponding normal values, the differences are not statistically significant. However, $\mathrm{Tm}_{\mathrm{G}}$ exceeded the mean normal plus 2 standard deviations in five of the 12 diabetic patients. Application of the binomial theorem indicates that the possibility of this occurring by chance alone is remote. Although patients with hypertension or those who had frank renal disease were excluded from the study, two of the female patients with low filtration rates (patients 8 and 12) were the only diabetics to have $T m_{G} s$ less than the mean normal value. $^{2}$

2 Three diabetic patients with frank renal disease were also studied but excluded from this report. These patients had glomerular filtration rates of 39,45 , and $70 \mathrm{ml}$. per

TABLE III

Glomerular filtration rate, $T m_{\mathrm{G}}$ and ratio of filtration rate to $T m_{\mathrm{G}}$ in non-diabetic and diabetic subjects

Glomerular filtration rate (GFR) and $T m_{G}$ values are corrected to a surface area of $1.73 \mathrm{sq} . \mathrm{m}$.

\begin{tabular}{|c|c|c|c|c|}
\hline Group & Patient & $\begin{array}{c}\text { Glomerular } \\
\text { filtration } \\
\text { rate }\end{array}$ & $T m_{G}$ & $\mathrm{GFR} / \mathrm{Tm}_{\mathrm{G}}$ \\
\hline \multirow{4}{*}{ Normal Male } & & $\begin{array}{l}\text { (ml. per } \\
\text { min.) }\end{array}$ & $\begin{array}{c}\text { (mgm. per } \\
\text { min.) }\end{array}$ & \multirow[b]{3}{*}{$\begin{array}{cc}0.371, \pm 0.0563 \\
0.25 \\
0.44 \\
0.34 \\
0.32 \\
0.35 \\
0.36\end{array}$} \\
\hline & Smith (8) & $131, \pm 21.5$ & $375, \pm 79.7$ & \\
\hline & $\begin{array}{l}13 \\
14 \\
15 \\
16 \\
17 \\
18\end{array}$ & $\begin{array}{l}132 \\
133 \\
125 \\
148 \\
125 \\
146\end{array}$ & $\begin{array}{l}521 \\
306 \\
372 \\
470 \\
354 \\
402\end{array}$ & \\
\hline & Average & 135 & 404 & 0.34 \\
\hline \multirow{3}{*}{ Normal Female } & Smith (8) & 117, \pm 15.6 & $303, \pm 55.3$ & $0.395, \pm 0.0617$ \\
\hline & $\begin{array}{l}19 \\
20 \\
21\end{array}$ & $\begin{array}{l}117 \\
143 \\
111\end{array}$ & $\begin{array}{l}414 \\
422 \\
322\end{array}$ & $\begin{array}{l}0.28 \\
0.34 \\
0.34\end{array}$ \\
\hline & \multicolumn{3}{|c|}{ 一 } & 一 \\
\hline \multirow[t]{2}{*}{ Diabetic Male } & $\begin{array}{l}1 \\
2 \\
3 \\
4 \\
5 \\
6\end{array}$ & $\begin{array}{l}120 \\
143 \\
104 \\
112 \\
164 \\
138\end{array}$ & $\begin{array}{l}415 \\
514 \\
402 \\
377 \\
619 \\
450\end{array}$ & $\begin{array}{l}0.29 \\
0.28 \\
0.26 \\
0.30 \\
0.26 \\
0.31\end{array}$ \\
\hline & Average & 130 & 463 & 0.28 \\
\hline \multirow[t]{2}{*}{ Diabetic Female } & $\begin{array}{r}7 \\
8 \\
9 \\
10 \\
11 \\
12\end{array}$ & $\begin{array}{r}120 \\
91 \\
117 \\
118 \\
140 \\
65\end{array}$ & $\begin{array}{l}438 \\
271 \\
419 \\
461 \\
495 \\
226\end{array}$ & $\begin{array}{l}0.27 \\
0.34 \\
0.28 \\
0.26 \\
0.28 \\
0.29\end{array}$ \\
\hline & Average & 103 & 356 & 0.30 \\
\hline
\end{tabular}

TABLE IV

Effect of insulin on $T m_{\mathrm{G}}$ and the ratio of glomerular filtration rate $(G F R)$ to $T m_{\mathrm{G}}$

\begin{tabular}{|c|c|c|c|c|c|c|c|}
\hline \multirow{2}{*}{ Group } & \multirow{2}{*}{ Patient } & \multicolumn{3}{|c|}{$\mathrm{Tm}_{\mathrm{G}}, \operatorname{mgm}$. per min. } & \multicolumn{3}{|c|}{$\mathrm{GFR} / \mathrm{Tm}_{\mathrm{G}}$} \\
\hline & & Control & Insulin & $\Delta$ & Control & Insulin & $\Delta$ \\
\hline \multirow[t]{2}{*}{ Diabetic } & $\begin{array}{r}1 \\
2 \\
3 \\
4 \\
5 \\
6 \\
7 \\
8 \\
9 \\
10 \\
11 \\
12\end{array}$ & $\begin{array}{l}415 \\
514 \\
402 \\
377 \\
619 \\
450 \\
438 \\
271 \\
419 \\
461 \\
495 \\
226\end{array}$ & $\begin{array}{l}352 \\
496 \\
361 \\
314 \\
539 \\
427 \\
394 \\
197 \\
401 \\
420 \\
445 \\
204\end{array}$ & $\begin{array}{l}-63 \\
-18 \\
-41 \\
-63 \\
-80 \\
-23 \\
-44 \\
-74 \\
-18 \\
-41 \\
-50 \\
-22\end{array}$ & $\begin{array}{l}0.29 \\
0.28 \\
0.26 \\
0.30 \\
0.26 \\
0.31 \\
0.27 \\
0.34 \\
0.28 \\
0.26 \\
0.28 \\
0.29\end{array}$ & $\begin{array}{l}0.37 \\
0.32 \\
0.29 \\
0.36 \\
0.28 \\
0.29 \\
0.32 \\
0.41 \\
0.30 \\
0.27 \\
0.31 \\
0.22\end{array}$ & $\begin{array}{l}+0.08 \\
+0.04 \\
+0.03 \\
+0.06 \\
+0.02 \\
-0.02 \\
+0.05 \\
+0.07 \\
+0.02 \\
+0.01 \\
+0.03 \\
-0.27\end{array}$ \\
\hline & Average & 424 & 379 & -45 & 0.27 & 0.31 & +0.04 \\
\hline Non-Diabetic & $\begin{array}{l}13 \\
14 \\
15 \\
16\end{array}$ & $\begin{array}{l}330 \\
372 \\
470 \\
402\end{array}$ & $\begin{array}{l}216 \\
396 \\
416 \\
404\end{array}$ & $\begin{array}{r}-114 \\
+24 \\
-54 \\
+2\end{array}$ & $\begin{array}{l}0.44 \\
0.34 \\
0.32 \\
0.36\end{array}$ & $\begin{array}{l}0.57 \\
0.32 \\
0.35 \\
0.36\end{array}$ & $\begin{array}{l}+0.13 \\
{ }_{-0.02}^{+0.03} \\
+0.00\end{array}$ \\
\hline
\end{tabular}

Normally glomerular and tubular functions are closely correlated and the ratio of glomerular filtration rate to $\mathrm{Tm}_{\mathrm{G}}$ is perhaps the most desirable means for comparison of $\mathrm{Tm}_{\mathrm{G}}$ among different groups of subjects. The average GFR/Tm $\mathrm{T}_{\mathrm{G}}$ ratios of the normal male and female subjects shown in Table III do not differ significantly from Smith's normal series. The ratios for the diabetic patients, however, are low. When the diabetics are compared to Smith's normal group, the $t$ values for the critical ratios are 5 for the males and 4 for females. These values are indicative of a highly significant increase of $\mathrm{Tm}_{\mathrm{G}}$ in relation to the glomerular filtration rate among the diabetics as compared to normals.

The difference between the male diabetic group and the normal group recorded in Table IV is barely significant, and the difference between the female diabetics and the three normal females is not significant. However, the normal groups in Table IV are so small that the comparison with Smith's larger series of normal subjects appears to be the more valid. The measurements of this study were made by techniques identical with those of Smith (8).

The filtration rates used to establish the GFR/ $T m_{G}$ ratios discussed above were those observed during the $\mathrm{Tm}_{\mathrm{G}}$ measurements. In five normal subjects and in 10 diabetics, glomerular filtration

minute, $T m_{G} S$ of 109,131 , and $183 \mathrm{mgm}$. per minute, and GFR/TmG ratios of $0.36,0.34$, and 0.38 respectively. The first two patients had chronic glomerulonephritis, the last one hypertensive renal disease. 
rate was measured before the start of the glucose infusions necessary for the $\mathrm{Tm}_{\mathrm{G}}$ observations. The filtration rate increased $1 \mathrm{ml}$. per minute on the average in the non-diabetic group, and decreased $7 \mathrm{ml}$. per minute in the diabetic group.

The administration of insulin reduced the $\mathrm{Tm}_{G}$ acutely in all 12 diabetic subjects studied (Table IV). The decrease ranged from 18 to $20 \mathrm{mgm}$. per minute with an average of $45 \mathrm{mgm}$. per minute. This represented an 11 per cent decrease. The ratio of $\mathrm{GFR} / \mathrm{Tm}_{\mathrm{G}}$ increased in 10 of the $12 \mathrm{sub}$ jects. This was mainly the result of changes in $\mathrm{Tm}_{\mathrm{g}}$ although slight increases in filtration rate contributed to the effect in several patients. The latter decreased only $1 \mathrm{ml}$. per minute on the average during the insulin periods as compared to those obtained during the measurement of $\mathrm{Tm}_{\mathrm{G}}$ without insulin. A progressive fall in filtration rate with no obvious explanation was noted throughout the study in one of the exceptions (patient 12). Insulin was also administered to four non-diabetic subjects (Table IV). A decrease in $T \mathrm{~m}_{\mathrm{G}}$ occurred in two of these subjects.

$\mathrm{Tm}_{\mathrm{G}}$ was measured in one diabetic patient during seven consecutive periods without the administration of insulin. The total length of this study was equal to the longest study in which insulin was administered. Throughout this control study the $\mathrm{GFR} / \mathrm{Tm}_{\mathrm{G}}$ ratio was constant and the difference between the lowest and the greatest $\mathrm{Tm}_{G}$ values was $26 \mathrm{mgm}$. per minute.

\section{DISCUSSION}

Five of 12 patients with mild to moderately severe diabetes, uncomplicated by known renal disease, were found to have $\mathrm{Tm}_{\mathrm{G}}$ values greater than the accepted normal range. ${ }^{3} \quad \mathrm{Tm}_{\mathrm{G}}$ was above the mean normal in 10 of the patients. The two exceptions had decreased glomerular filtration rates although hypertension, proteinuria or other evidences of renal disease were absent. The reduction in renal functions in these patients may have been due to arteriosclerosis of the kidneys, or perhaps represented the early stages of intercapillary glomerulosclerosis.

\footnotetext{
3 Richardson (9), working independently, has found the $T m_{G}$ to be greater than the normal range in six of 14 diabetic patients.
}

The ratio of filtration rate to $\mathrm{Tm}_{\mathrm{G}}$ was significantly reduced among the diabetic patients. This appeared to be the result of increased $\mathrm{Tm}_{\mathrm{G}}$ values rather than of decreased glomerular filtration rates, for in the majority of patients the filtration rates were in the normal range. In addition, the low filtration rate to $T m_{G}$ ratios were not due to possible alterations in glomerular activity induced by the glucose infusions.

The administration of insulin decreased the $\mathrm{Tm}_{\mathbf{G}}$ in each of 12 diabetics tested and increased the $\mathrm{GFR} / \mathrm{Tm}_{\mathrm{G}}$ ratio toward normal in 10 of the 12 . Insulin decreased the $\mathrm{Tm}_{\mathrm{G}}$ in two of four non-diabetic subjects. Although slight decreases in plasma glucose levels usually occurred after insulin administration, this was kept at a minimum by the sustaining infusion of glucose. In any case, adequate glucose load to $\mathrm{Tm}$ ratios were maintained throughout the studies.

The decreased $\mathrm{Tm}_{\mathrm{G}}$ after insulin was not due to increased utilization of glucose by the renal tubules for this would be reflected by an apparent increase in $\mathrm{Tm}_{\mathrm{G}}$. Whether the effect of insulin on the $\mathrm{Tm}_{\mathrm{G}}$ was due to insulin itself or to a contaminant such as the "hyperglycemic factor" (10) is not certain. However, in the present experiments and in the doses used, insulin given intravenously did not raise the blood glucose values.

An increase of $\mathrm{Tm}_{\mathrm{G}}$ in diabetes might be attributed to insulin deficiency itself or might be secondary to other hormonal imbalances that may play a role in diabetes. The reduction of $\mathrm{Tm}_{\mathrm{G}}$ effected by insulin is not readily explicable on the basis of the usual concepts of insulin action. Offhand, a greater ability of the renal tubule cells to transport glucose would be expected. But in any case, the decreased $\mathrm{Tm}_{\mathrm{G}}$ after insulin may explain clinical observations in diabetics that are reported from time to time such as: "after prolonged insulin therapy the urine may contain sugar even though the blood sugar is much lower than before treatment and the urine may have been negative before insulin therapy was instituted" (1).

Since insulin decreases $\mathrm{Tm}_{\mathrm{G}}$ in diabetics, it is possible that the differences between the GFR ' $\mathrm{Tm}_{\mathrm{G}}$ ratios of diabetics and non-diabetics may be the result of increased secretion of endogenous insulin in the non-diabetic occasioned by the rather large loads of glucose. This endogenous insulin 
would lower the $\mathrm{Tm}_{\mathrm{G}}$ perhaps maximally and additional exogenous insulin would thus have little or no effect. In line with this hypothesis was the failure of insulin to reduce $\mathrm{Tm}_{\mathrm{G}}$ in two of the four normal subjects tested. In the diabetics the glucose load does not call forth as much insulin, and exogenous insulin would be free to exert its ability to reduce $\mathrm{Tm}_{\mathrm{G}}$. In view of the equilibration period allowed to achieve relatively stable plasma glucose levels, this point could not be critically examined. However, a downward trend in $\mathrm{Tm}_{G}$ was not apparent in successive periods among the non-diabetic subjects.

\section{CONCLUSIONS}

1. The maximum capacity of the renal tubules to reabsorb glucose is above the normal range in a significant proportion of patients with mild to moderately severe diabetes.

2. When related to the glomerular filtration rate, the glucose reabsorptive capacity is increased in diabetics without renal disease.

3 . Insulin reduces the glucose reabsorptive capacity of diabetics.

\section{REFERENCES}

1. Yardumian, K. Y., and Alpern, A. N., Clinical and laboratory observations on so-called "kidney threshold for glucose.” Am. J. Clin. Path., 1941, $11,425$.

2. Mirsky, I. A., and Nelson, N., Significance of glycosuria. Arch. Int. Med., 1943, 71, 827.

3. Shannon, J. A., and Fisher, S., The renal tubular reabsorption of glucose in the normal dog. Am. J. Physiol., 1938, 122, 765.

4. Shannon, J. A., Farber, S., and Troast, L., The measurement of glucose $\mathrm{Tm}$ in the normal dog. Am. J. Physiol., 1941, 133, 752.

5. Eiler, J. J., Althausen, T. L., and Stockholm, M., The effect of thyroxin on the maximum rate of transfer of glucose and diodrast by the renal tubules. Am. J. Physiol., 1943, 140, 699.

6. Harrison, H. E., A modification of the diphenylamine method for the determination of inulin. Proc. Soc. Exper. Biol. \& Med., 1942, 49, 111.

7. Alving, A. S., Rubin, J., and Miller, B. F., A direct colorimetric method for the determination of inulin in blood and urine. J. Biol. Chem., 1939, 127, 609.

8. Smith, H. W., Lectures on the Kidney. Univ. Extension Div., Univ. of Kansas, Lawrence, Kansas, 1943.

9. Richardson, F. M., Personal communication.

10. Bouckaert, J. P., and de Duve, C., The action of insulin. Physiol. Rev., 1947, 27, 39.

\section{SPECIAL NOTICE TO SUBSCRIBERS}

Post Offices will no longer forward the Journal when you move.

Please notify Journal of Clinical Investigation, Business Office, c/o Cincinnati General Hospital, Cincinnati 29, Ohio, at once when you have a change of address and do not omit the zone number if there is one. 